\title{
ICT Integration in Academic Writing: Some Fruitful Pedagogical Applications
}

\author{
Justin James* \\ English Language Centre, Nizwa College of Technology, Ministry of Manpower, \\ Sultanate of Oman; justin.james@nct.edu.o
}

\begin{abstract}
Effective use of technology in language teaching depends on the role and content of the materials used and how they interact with each student's language learning experience. Incidentally, the present generation of students, being digitally-literate finds anything to do with the internet generally attractive. Students' normal interests in browsing the internet can be fruitfully tapped for a variety of language learning purposes and also to ensure a higher degree of motivation and participation. This paper aims at reporting and sharing a systematically developed and successfully executed ICT-integrated language lesson delivered at English Language Centre, Nizwa College of Technology under the guidance of The Consultant-E Online Training and Development Consultancy, Spain. This paper demonstrates how various ICT tools can be incorporated in teaching academic writing.
\end{abstract}

Keywords: Class Blog, Collaborative Learning, Quizlet Quiz, Screen Shots, ED, WebQuest

\section{Introduction}

ICT integration in Academic Writing proved to be a fruitful venture in teaching Post Foundation Writing courses at the English Language Center, Nizwa College of Technology. Technical Communication is an academic, content based writing course for Diploma level students of Engineering and IT specializations. The reported lesson was delivered in a class consisting of 26 students in the third year of the Five year long Bachelor's Degree Course during the Winter semester of 2011(January-April).The students had completed a four semester foundation program and had passed the institutional TOEFL exam. The class was divided into 5 groups. This experiment was conducted with the conviction that the use of internet technology "in foreign/second language education offers a unique opportunity for interaction which can be a valuable substitute for a real experience [3]".

The Syllabus of the Technical Communication course includes writing extended definitions, describing charts, comparison of charts and writing persuasive essays. I found the lesson on writing an extended definition perfectly suitable for introducing ICT tools. Writing is usually considered monotonous by students, so the introduction of new tools was a welcome change to them for they were good at using computers and internet. I decided to integrate three ICT tools in this lesson: Quizlet Quiz, WebQuest and Blog (Appendix I). The expected learning outcomes were:

1. Students should learn to write an extended definition of a technology/machine/simple electronic device etc.

2. Students should learn to use the rhetoric they had learned in the lower levels as tools to write an extended definition.

3. They should learn to use WebQuest to collect information.

The purpose of this paper is to share my experience with fellow English language teachers as it is perceived that " To cope with the digital age, teachers should understand that 21st century learners have different ways of thinking and different practices which are closely connected to technology" (Lee et al., 2004; Warlick,2001, quoted in Labbas and Shaban [4]). The report includes my reflections on planning the lesson, teaching the lesson, perceived learner experience, teacher experience and suggestions for integration of ICT in ELT.

\section{${ }^{*}$ Author for correspondence}




\section{Reflections on Planning}

\subsection{Planning the Lesson}

Planning an ICT based lesson was a real challenge in my context. I call it a challenge because it involved selection of suitable ICT tools, integrating them to the delivery of the current lesson and using them suitably to achieve the learning outcomes envisaged for the course.

In the first place, delivering a content based lesson to the students in the present context is a challenge by itself. The reasons are their limited general knowledge, general awareness and English language competency. Therefore, getting them to write an extended definition of machines, devices and technologies is a herculean task. Even, Diploma level students need to be provided with the required vocabulary, sentence patterns, sample compositions and also the content for their writing exercises. However, I saw this situation as the right context to use the chosen ICT tools successfully. I used Quizlet Quiz (Appendix II) to provide them with the required vocabulary, WebQuest (Appendix IV) to help them collect information about select topics and $\underline{\text { Class }}$ Blog (Appendix III) to encourage collaborative learning by way of peer evaluation, comparing their compositions etc.

The immediate outcome targeted was breaking the monotony of photocopies, pens and papers in the writing classroom. The intended long term outcome was introducing ICT based learning techniques to make students independent learners and to create an awareness of the assistance offered by computers and internet for their learning.
After enough brainstorming, a detailed step-by-step lesson plan was prepared, specifying all the activities of teachers and students inside and outside class. The lesson involved the use of computers, internet, smart board, LCD projector etc., so I thought of the problems that might crop up during the lesson, and prepared a plan B to overcome them. I was ready with the alternate materials required. I kept the subsequent class open for completing the lesson. In short, I had to do a lot of research and homework during the planning stage.

\section{Plan B: Anticipated problems and suggested solutions \\ Problems}

1. Slow speed of Internet making accessibility difficult while teaching.

2. Power failure

3. Equipment failure

4. Students' inability in using ICT tools.

\section{Solutions}

1. Use screenshots of the intended activities from the websites.

2. Use local server / e-learning portal in the college website for student activities.

3. Use photocopies of the required materials (hand-outs, WebQuest etc.)

4. Tutorials to assist / enable students to use ICT tools.

\subsection{Lesson Plan}

\begin{tabular}{|c|c|c|c|}
\hline Stage & Procedure & Time & Aim \\
\hline 1. & $\begin{array}{l}\text { Review: What is definition? } 3 \text { types of Definition. What } \\
\text { is extended definition and how the Extended Definition } \\
\text { (ED) of Nano Technology was written? (Instruct students } \\
\text { to take the Quiz on Quizlet before the deadline) }\end{array}$ & 10 minutes & $\begin{array}{l}\text { Jog students' memory + prepare them } \\
\text { to write an Extended Definition (ED). }\end{array}$ \\
\hline 2. & $\begin{array}{l}\text { Pair Work: Students read the table and recollect the rheto- } \\
\text { rics they've learned before and are going to be used as tools } \\
\text { for Writing an ED. Students are asked to recollect some } \\
\text { topics that they wrote about while learning these rhetorics. }\end{array}$ & 15 minutes & $\begin{array}{l}\text { They are made to understand that their } \\
\text { previous knowledge is used in writing } \\
\text { ED. Example topics are asked for ensur- } \\
\text { ing their understanding of the tools. }\end{array}$ \\
\hline 3. & $\begin{array}{l}\text { Plan: (Pair work) Students are given the topic HD TV and } \\
\text { are asked to brainstorm and make a plan for their ED on } \\
\text { it. They refer to the model plan in the handout. Each pair } \\
\text { is asked to say one of the tools chosen by them and teacher } \\
\text { writes the plan of the ED on the White Board. }\end{array}$ & 20 minutes & $\begin{array}{l}\text { Students brainstorm, choose, discuss } \\
\text { and arrive at a common plan for the } \\
\text { Extended Definition. This will help } \\
\text { them to plan individually at later stages. }\end{array}$ \\
\hline 4. & Students read the essay on Greenhouse Effect. & 15 minutes & $\begin{array}{l}\text { Understand how ED gives a clear } \\
\text { insight into a topic. }\end{array}$ \\
\hline
\end{tabular}




\begin{tabular}{|c|c|c|c|}
\hline 5. & $\begin{array}{l}\text { Teacher issues Assignment topic (HW) - Write an ED on } \\
\text { Kindle. Teacher displays the task description posted on } \\
\text { Moodle and explains the steps: Understanding the topic, } \\
\text { planning the ED, collecting information, writing the ED in } \\
\text { a group and how to post it on the Class Blog. Teacher elabo- } \\
\text { rates on collecting information using WebQuest, shows the } \\
\text { hyperlinks given in the H.W. description on Moodle and } \\
\text { explains how they take them to the relevant sites quickly. }\end{array}$ & 20 minutes & $\begin{array}{l}\text { Students see the WebQuest and under- } \\
\text { stand how to use it to collect informa- } \\
\text { tion easily and quickly. (Appendix IV) }\end{array}$ \\
\hline 6. & $\begin{array}{l}\text { Teacher: Explains the process of pooling information, } \\
\text { discussing in their groups and writing the ED, editing it and } \\
\text { posting it in the class Blog. (Appendix V) Teacher: Explains } \\
\text { the advantages of posting the ED in the Blog. Teacher shows } \\
\text { the link that helps to log on to the Blog, and demonstrates } \\
\text { how comments can be posted right below the posting. } \\
\text { (Appendix VI) Students: Get feedback on their work from } \\
\text { peers (peer evaluation) Students: Get to read peer composi- } \\
\text { tions and improve - by comparing and contrasting with oth- } \\
\text { ers postings (Self-evaluation) and can see teacher's feedback } \\
\text { on all compositions.(Teacher's feedback) (Appendix VIII) }\end{array}$ & 20 minutes & $\begin{array}{l}\text { Encourage students to use a class blog } \\
\text { as a discussion forum. (Appendix III) } \\
\text { Students understand that blog is an } \\
\text { effective tool for collaborative learning } \\
\text { and a place for showcasing their writ- } \\
\text { ten compositions. (Appendix VII) }\end{array}$ \\
\hline
\end{tabular}

\subsection{Structure and Content of an Extended Definition}

\begin{tabular}{|l|l|}
\hline Introduction & $\begin{array}{l}\text { - A brief definition of the term/object (a formal sentence definition } \\
\text { - Overview of the tools/rhetoric used in the body }\end{array}$ \\
\hline Body paragraph 1 Tool 1 & $\begin{array}{l}\text { - Heading stating the tool being used } \\
\text { - Explain the term/object using the tool } \\
\text { - Provide supporting details and examples }\end{array}$ \\
\hline Body paragraph 2 Tool 2 & $\begin{array}{l}\text { - Heading stating the tool being used } \\
\text { - Explain the term/object using the tool } \\
\text { - Provide supporting details and examples }\end{array}$ \\
\hline Body paragraph 2 Tool 3 & $\begin{array}{l}\text { - Heading stating the tool being used } \\
\text { - Explain the term/object using the tool } \\
\text { - Provide supporting details and examples }\end{array}$ \\
\hline Conclusion & $\begin{array}{l}\text { - Give opinion about the term/object defined } \\
\text { - Give pertinent suggestions }\end{array}$ \\
\hline
\end{tabular}

Note: The tools/rhetoric used in Extended Definition are Description, Division/Classification, Process, Causes/Effects and Problem/Solution.

\section{Reflections on Teaching}

\subsection{The Main Lesson}

Students found writing Extended Definitions interesting as they were applying the writing tools learnt in lower levels for a bigger purpose. They were excited about using the ICT tools for completing their homework. Students were asked to complete the WebQuest and prepare an outline for the Extended Definition before the next class.

\subsection{The Follow-up Class}

Though 6 out of 26 students had not done the WebQuest, 4 out of 5 groups had completed the WebQuest successfully and had collected the required information. They had even prepared an outline for their Extended Definition. Their feedback on WebQuest was very positive. I understood that they used to spend a lot of time in searching for information, despite using search engines. They had to look into many sites before getting enough information, but the

HuSS: International Journal of Research in Humanities and Social Sciences 
WebQuest task made the search easy as the hyperlinks lead them directly to the appropriate information. After checking their outlines and giving necessary guidelines to write the Extended Definition, I started demonstrating the steps in Blog Posting. Unfortunately, the class Blog Tec Comm 2011 could not be accessed due to the slow speed of the internet. So I used the screenshots (Appendix III \& IV) to explain the steps. Students' enthusiasm was quiet evident in their active participation.

\section{Perceived Learner Experience}

- Anything to do with internet is a great attraction for students as they are "digital natives" [1]. Their natural interest in browsing the internet could be tapped for learning purposes.

- Students were eager to use the ICT tools, and their enthusiasm and participation were very high compared to non ICT lessons.

- Webquest equipped them with the content to engage in group work and collaborative learning, confidently.

- They were also able to complete the writing exercise within the stipulated time. Usually, they take a long time to complete such a task when they are left on their own to search the web, find information and write the essays. WebQuest helped them to do a quick and focused search.

- Students benefitted by self and peer evaluations on the Blog; the less motivated students were inspired to write as they were eager to post their compositions on the blog.

- Students took part in discussions with their course mates to clear their doubts, share information and express concerns about their course etc., in the Blog.

- Blog proved to be a good medium of communication in the present context because many of the students, especially girls, feel shy to express their views in the mixed classrooms.

\section{Overall Teacher Experience}

- $75 \%$ of students had successfully used WebQuest. (25\% gave acceptable reasons including not having internet access at their homes, but they benefited by their discussions in their respective groups).

- ICT tools were successfully used for teaching (Quizlet Quiz, Webquest and Blog).

- Students were enthusiastic about web quest and blogs as they are a change from the monotony of books, papers and red ink. I decided to continue using the blog with this group of students and make WebQuest an integral part of all assignments.

\section{Suggestions for Integration of ICT in ELT}

- Tools like Blog should be introduced at the beginning of the semester (course introduction week) as an open forum. This approach will make students learn to use Blogs freely and unconditionally as a messenger among course mates and later it can be turned into a medium of collaborative learning.

- Only tools which are directly helpful in the lessons should be introduced along with the lesson. E.g. Online quiz or WebQuest.

- Try to prescribe relevant ICT tools in the syllabus and award marks/grades for the use of these tools.

- Workshops should be arranged for teachers to introduce ICT tools and how to integrate them in ELT.

- Teachers should be provided with required equipment and technical support to encourage them to use ICT.

\section{Conclusion}

"Learning has always involved creativity and in all sectors of education and training the (use of) practical assignment to produce an agreed outcome has been shown to be very effective..." [2]. The lesson experiment reported has become another successful example for the above statement. This lesson taught me how the current interests of students can be used as tools for teaching/learning. I understood that use of technology increases the learners' academic performance because it can "enable students to enjoy immediate individual feedback, work independently (and in groups), and gain a sense of accomplishment" (Lovell and Phillips, 2009, quoted in Shaban [5]). I realized how much planning and work are required to be an innovative teacher and how innovations must be inherent in a teacher to be successful. The lesson has showed me that such academic pursuits are essential to keep abreast of the new developments in the ELT world and to be successful, throughout the career.

\section{ICT Tools Used}

1. A Quizlet flashcard quiz - This quiz announcement is posted in college website: http://www.nct.edu.om/ moodle/login/index.php

2. A teacher prepared WebQuest on "Kindle" posted in college website:

http://www.nct.edu.om/moodle/login/index.php

HuSS: International Journal of Research in Humanities and Social Sciences 
3. The class Blog, Tec Comm 2011, http://teccomm2011. blogspot.com/

\section{Sites / Technology}

1. http://en.wikipedia.org/wiki/File:Amazon_Kindle_3.JPG

2. http://www.rayfowler.org/2010/03/31/top-ten-kindlefeatures/

3. http://www.articlesbase.com/computers-articles/ advantages-and-disadvantages-of-the-amazon-kindledx-1133043.html

4. http://www.amazon.com/gp/product/B0015T963C

5. http://www.scribd.com/doc/3933552/Kindle-Thefuture-of-book-reading

6. http://teccomm2011.blogspot.com/

7. http://quizlet.com/4473235/test/?written=on\&mult_ choice $=$ on\&tf $=$ on\&ignore - case $=1$ \&prompt def $=1$ \&limit $=6$
8. http://www.nct.edu.om/moodle/login/index.php

\section{References}

1. Barrett B., and Sharma P., Blended learning: using technology in and beyond the language classroom. Macmillan, 2007.

2. Clarke A., E-Learning Skills. Macmillan, 2008.

3. Kruk M., The use of internet resources and browser-based virtual worlds in teaching grammar, Teaching English with Technology Online Journal, vol. 14(2), p. 51-66, 2014. Available:http://www.tewtjournal.org/VOL\%202/ARTICLES 3.pdf

4. Labbas R., and El Shaban A., Teacher development in the digital age. Teaching English with Technology Online Journal, vol. 13(3), p. 53-64, 2013. Available: http://www.tewt journal.org/VOL\%2013/ISSUE\%203/ARTICLE4.pdf.

5. El Shaban A. (Reviver), Software Review of U.S.A. Learn, Teaching English with Technology online Journal, vol. 13(2), p. 83-97, 2013. Available: http://www.tewtjournal.org/VOL\%2013/ISSUE\%202/ARTICLE5.pdf

\section{Appendix Overleaf}


Appendix I.

${ }^{*}$ Quizlet (http://quizlet.com/help/what-is-quizlet) is a free website providing learning tools for students, including flashcards, study and game modes. It was created by high school sophomore Andrew Sutherland in 2005 and now contains over 30 million study sets. All of the material is user-generated.

${ }^{*}$ Web Quest (http://en.wikipedia.org/wiki/WebQuest) is an inquiry-oriented lesson format in which most or all the information that learners work with comes from the web. These can be created using various programs, including a simple word processing document that includes links to websites.

*A blog (http://en.wikipedia.org/wiki/Blog) is a discussion or informational site published on the World Wide Web and consisting of discrete entries ("posts") typically displayed in reverse chronological order. Until 2009 blogs were usually the work of a single individual, occasionally of a small group, and often covered a single subject.

\section{Appendix II. A Screenshot of Quizlet Quiz}

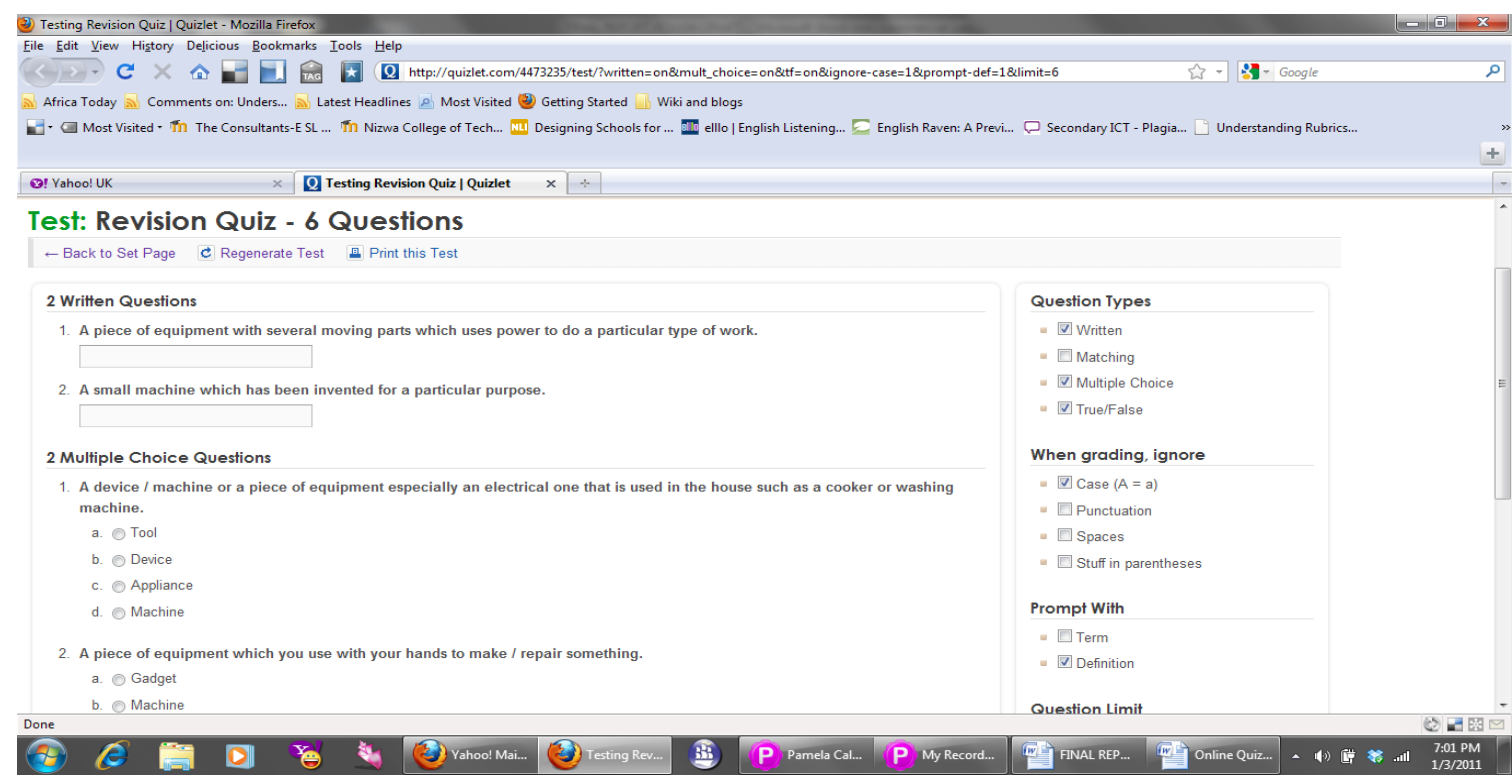

Appendix III. A Screenshot of Class Blog

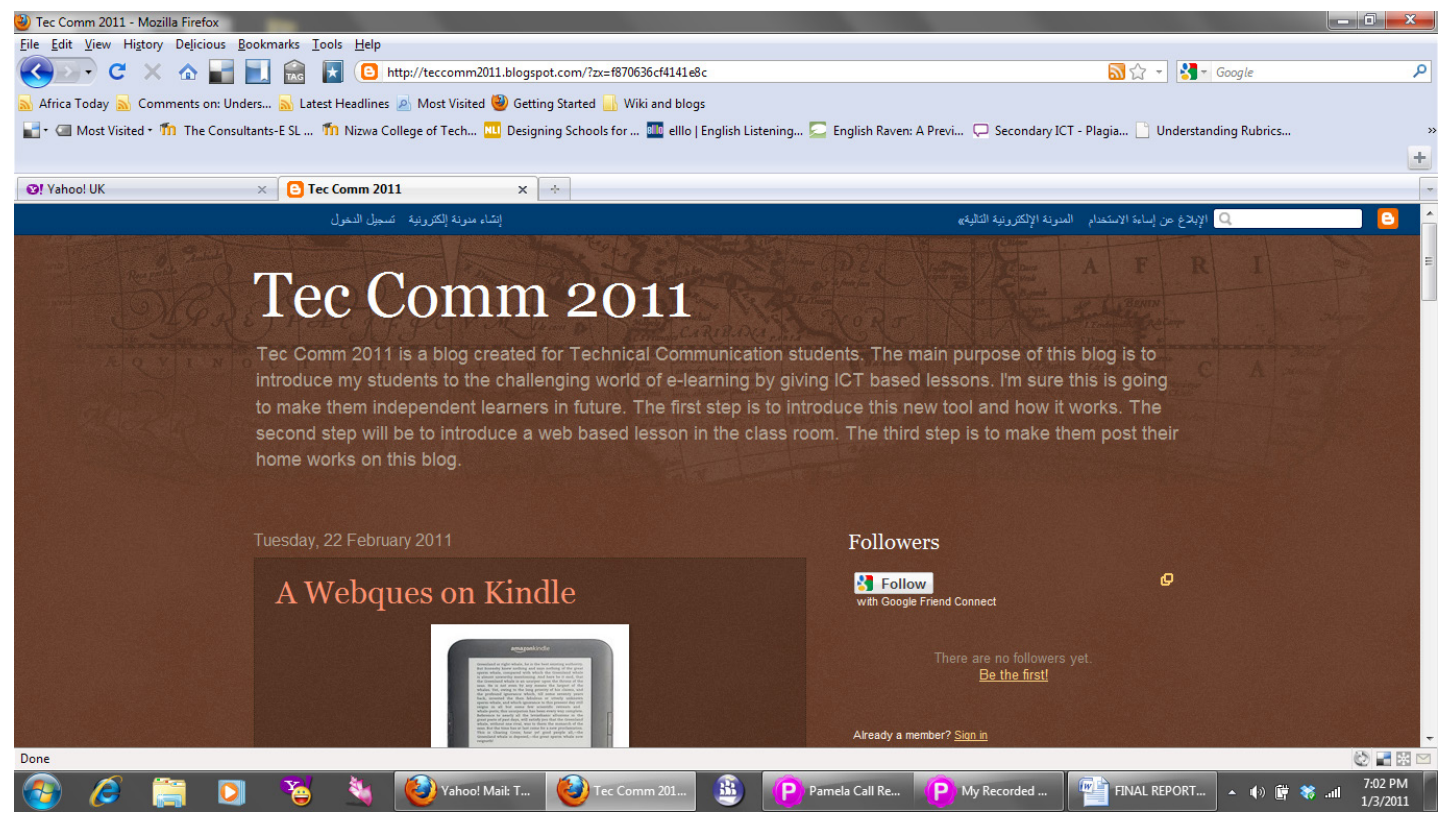




\section{Appendix IV. Web Quest on Amazon Kindle}

Amazon Kindle - Amazon kindle is a portable wireless reading device. It is a device used to read digital copies of books, newspapers, magazines, and blogs. The device uses a digital screen to show an image of a printed page. You can read more on: Wikipedia information on Kindle history.

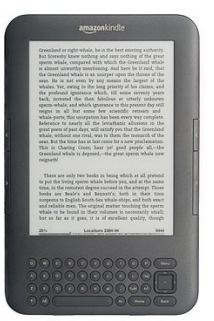

Task: Writing an Extended Definition on Amazon Kindle

Process:

1. Make a plan for your extended definition after reading the short introduction on Kindle. You can refer to the sample plan you prepared on HD TV in the class.

2. When the plan is ready visit the following sites to collect relevant information.

Click on this links to go to the sites: a. Features and Types of Kindle
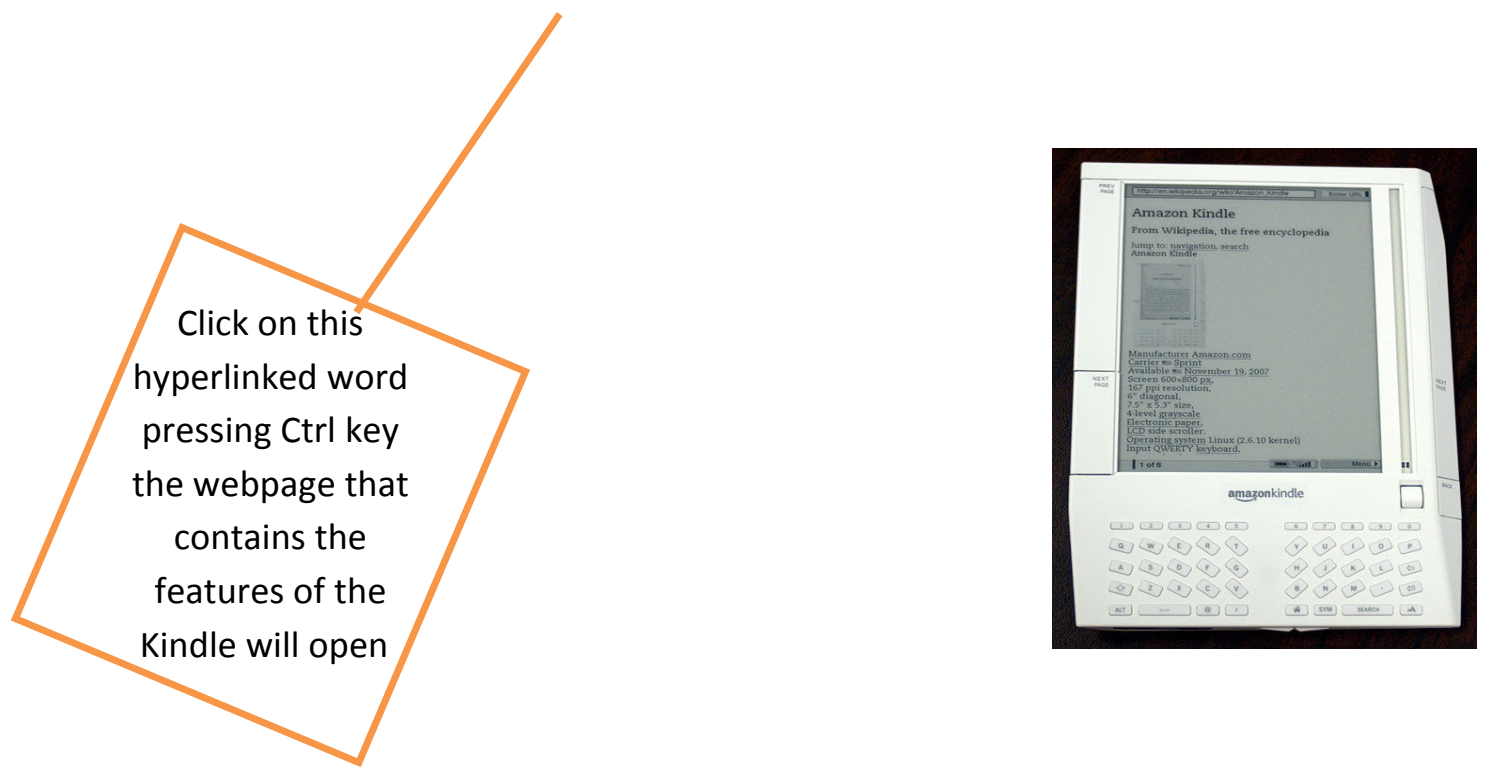

b. Advantages and Disadvantages of Amazon Kindle

c. Watch the video about the features of Kindle

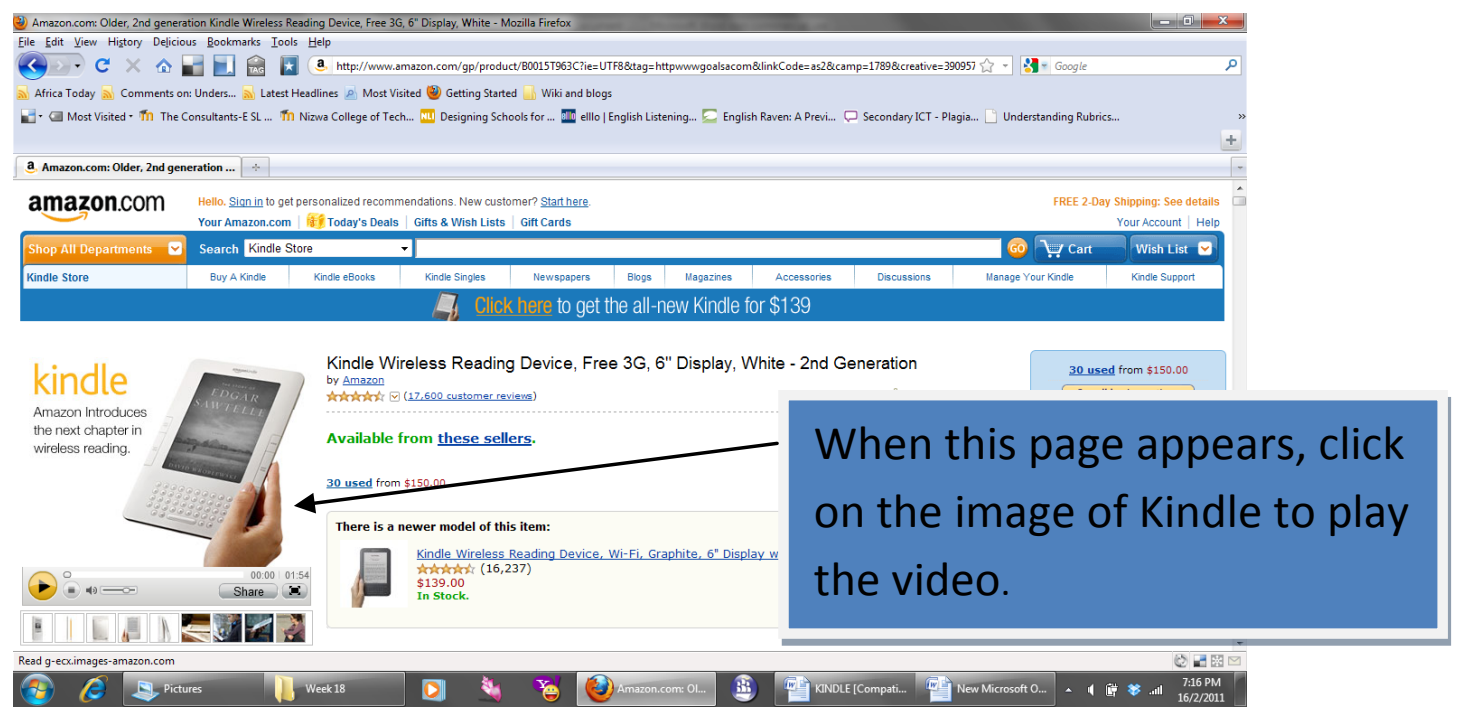


e. Kindle - the future of book reading.

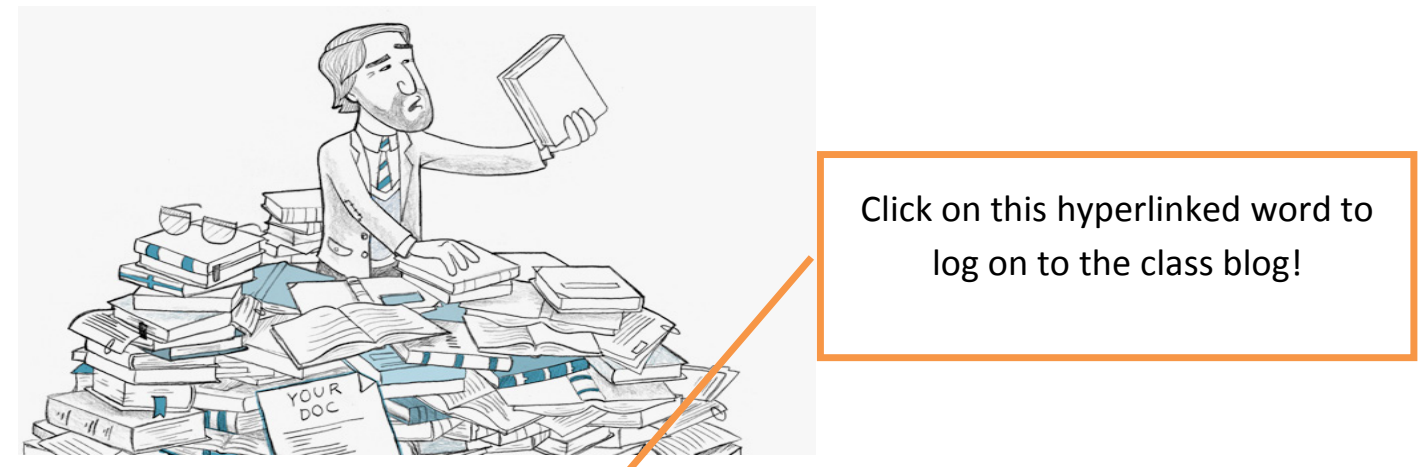

3. Next, all the students in a group must get together outside class hours to pool the information you have collected and decide on what is to be used in your essay of 1000 words.

4. After the discussion, each groap must write an extended definition collectively and post it on the class blog Tec Comm 2011.

\section{Evaluation:}

You can evaluate your composition in 3 ways when you post it on the Blog:

1. Read other postings, compare yours with them and improve yours (Self-evaluation).

2. Request others to comment on your writing and learn your strengths and weaknesses (Peer-evaluation).

3. You can see teacher's comments about all postings and understand the ratings (Teacher-evaluation).

\section{Teacher Notes:}

- Do not copy, paste information from the sources. Present the information in your own words.

- Do not exceed 300 words.

- Deadline for posting is $26 / 02 / 2011$.

Appendix V. How to add postings in the Blog Tec Comm2011?

1. Sign in with the Google account:

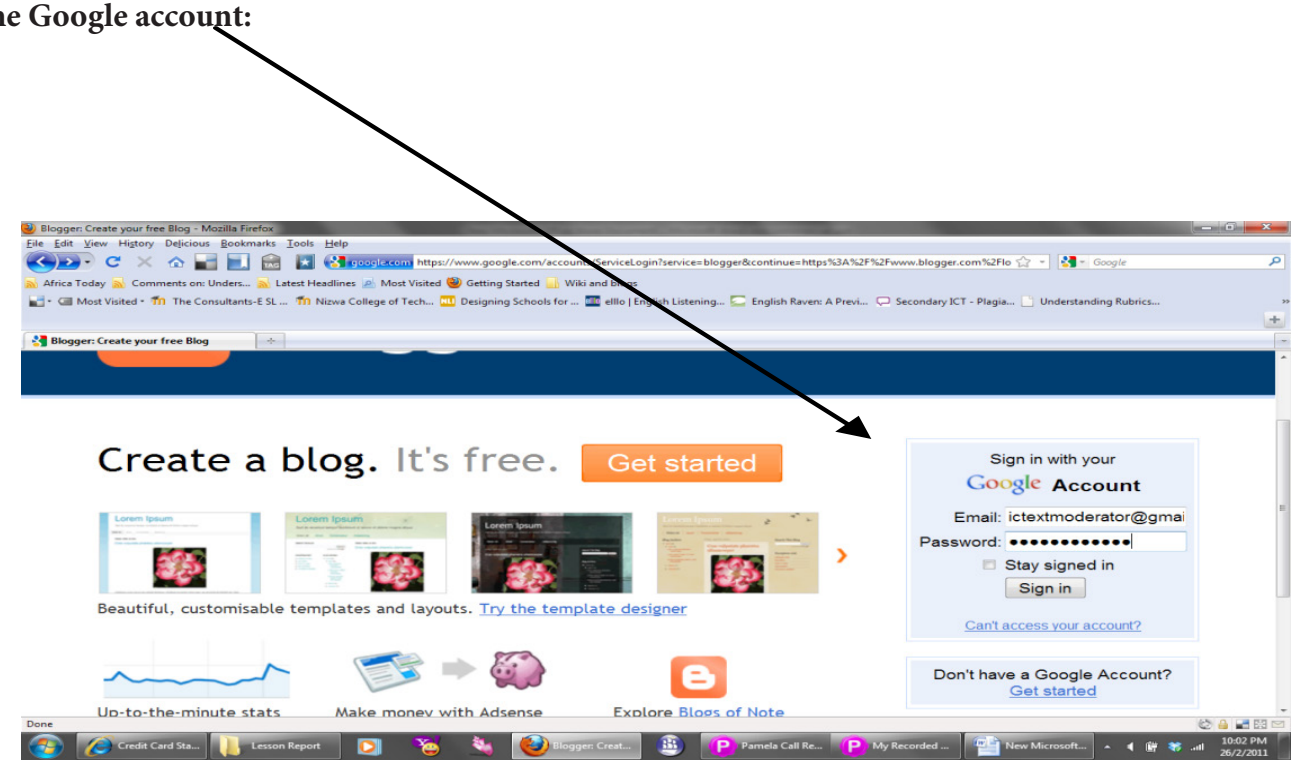


2. When you sign in, the "blogger dashboard" will appear:

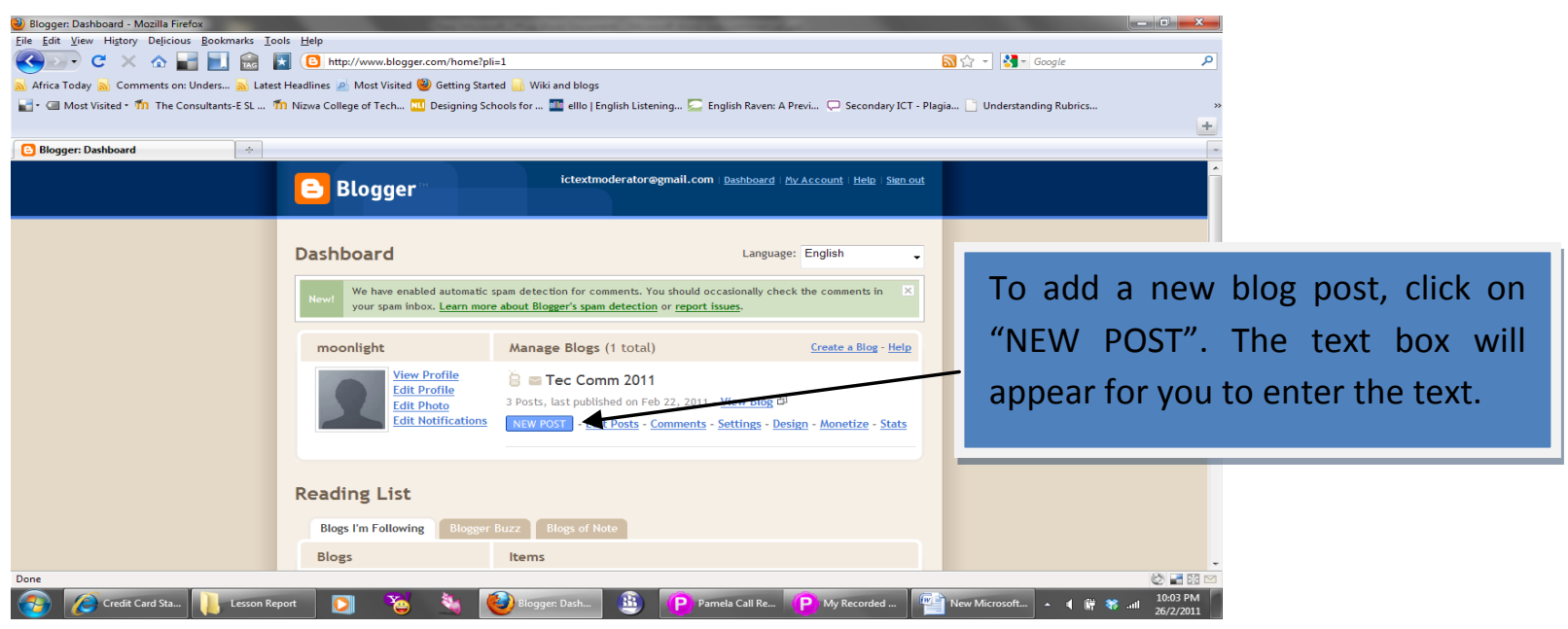

3. Enter the text in the text box:

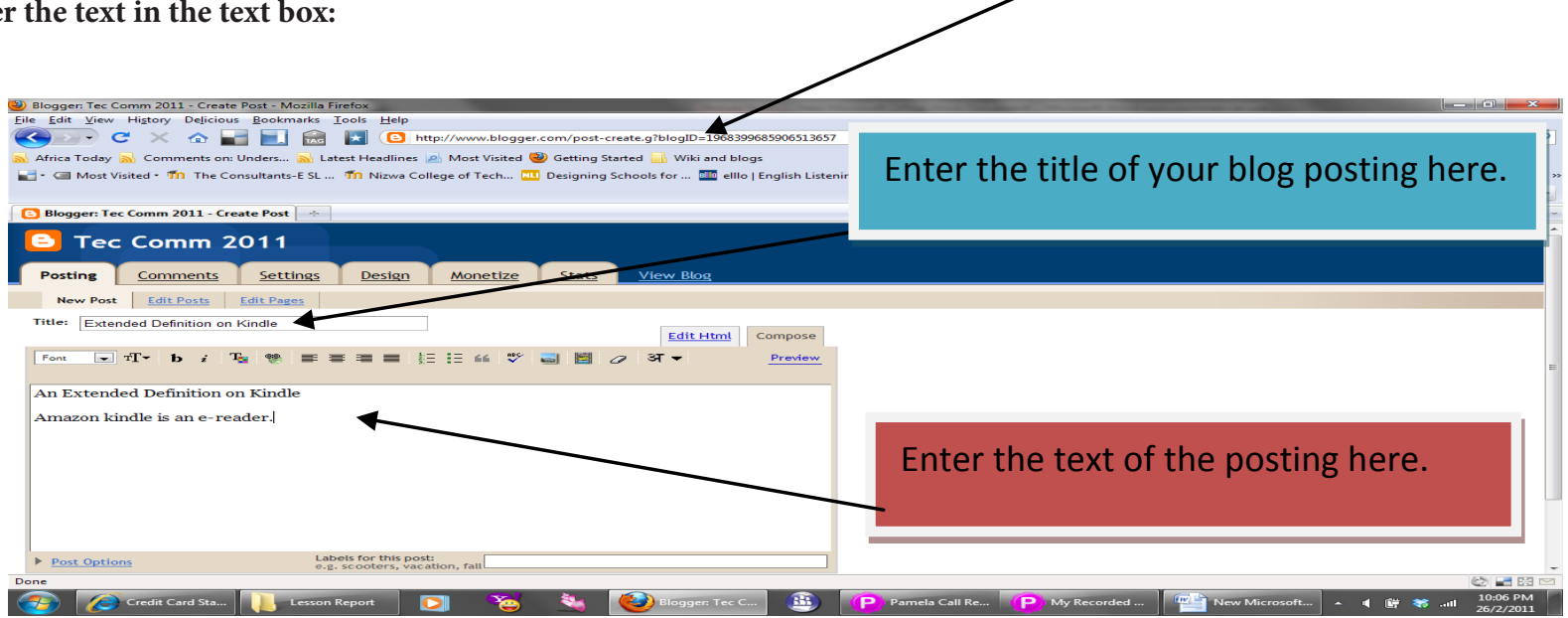

4. To add a picture, image or photo:

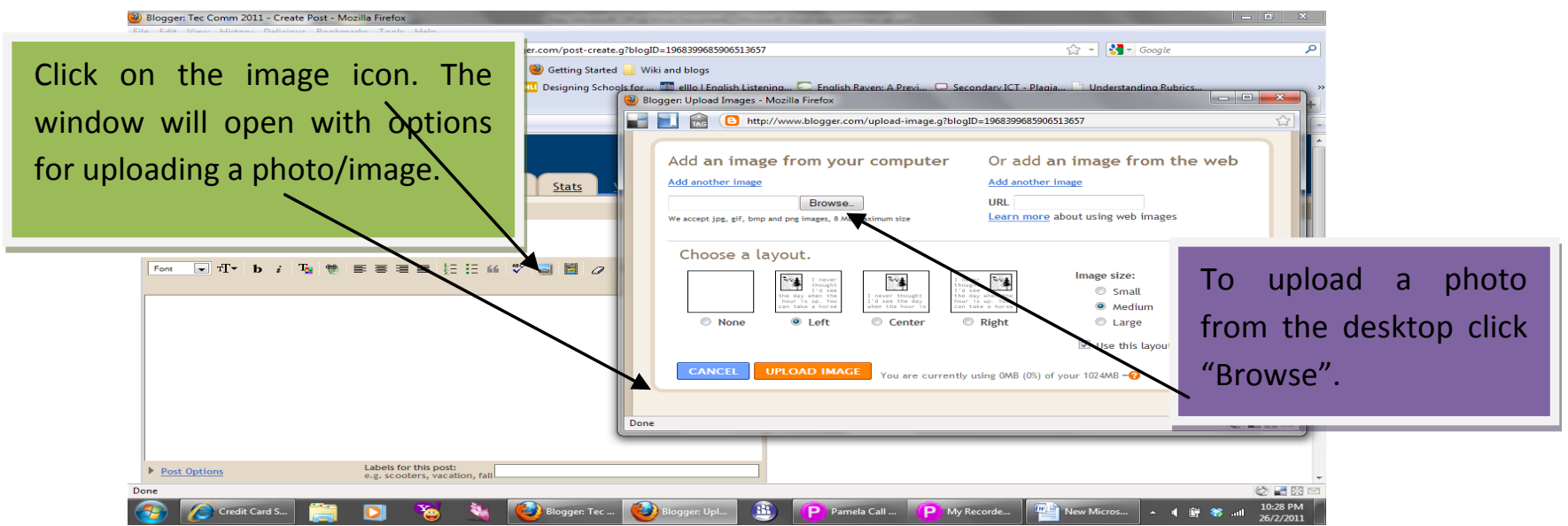


5. Selecting image/photo/ picture from the desktop:

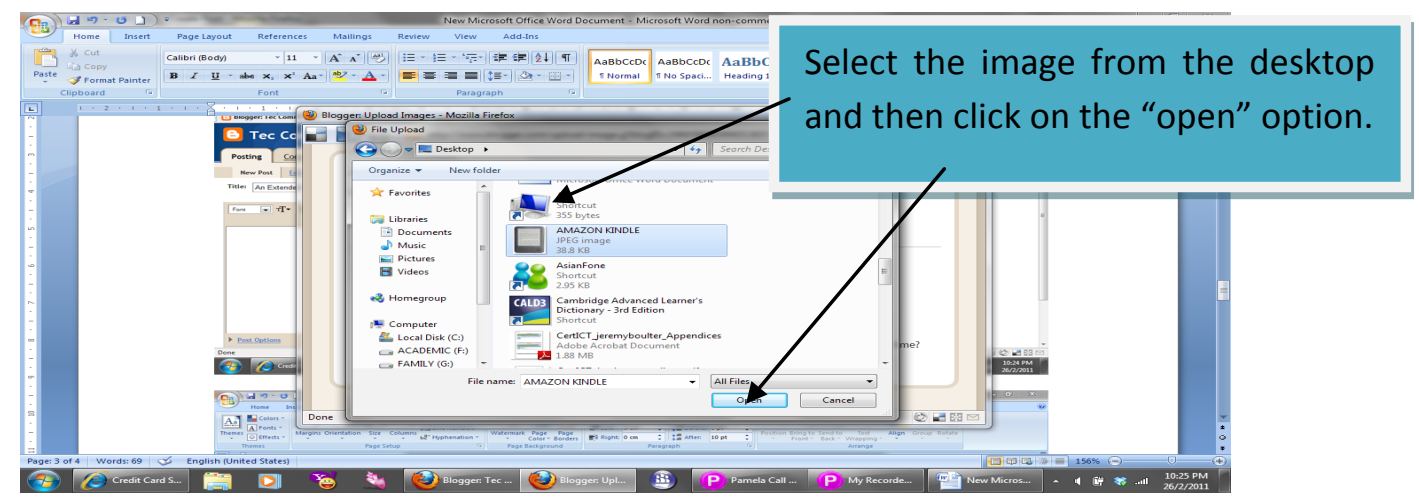

6. Upload the selected image/photo/picture:

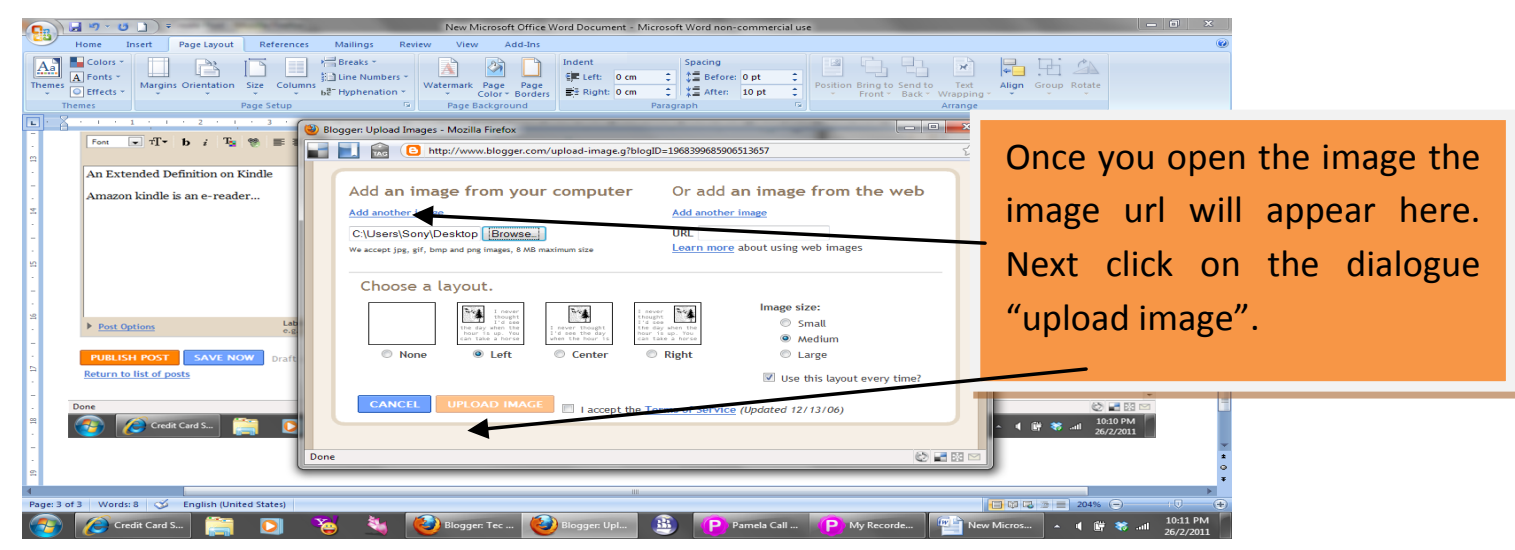

7. View the uploaded image and preview the Blog Posting

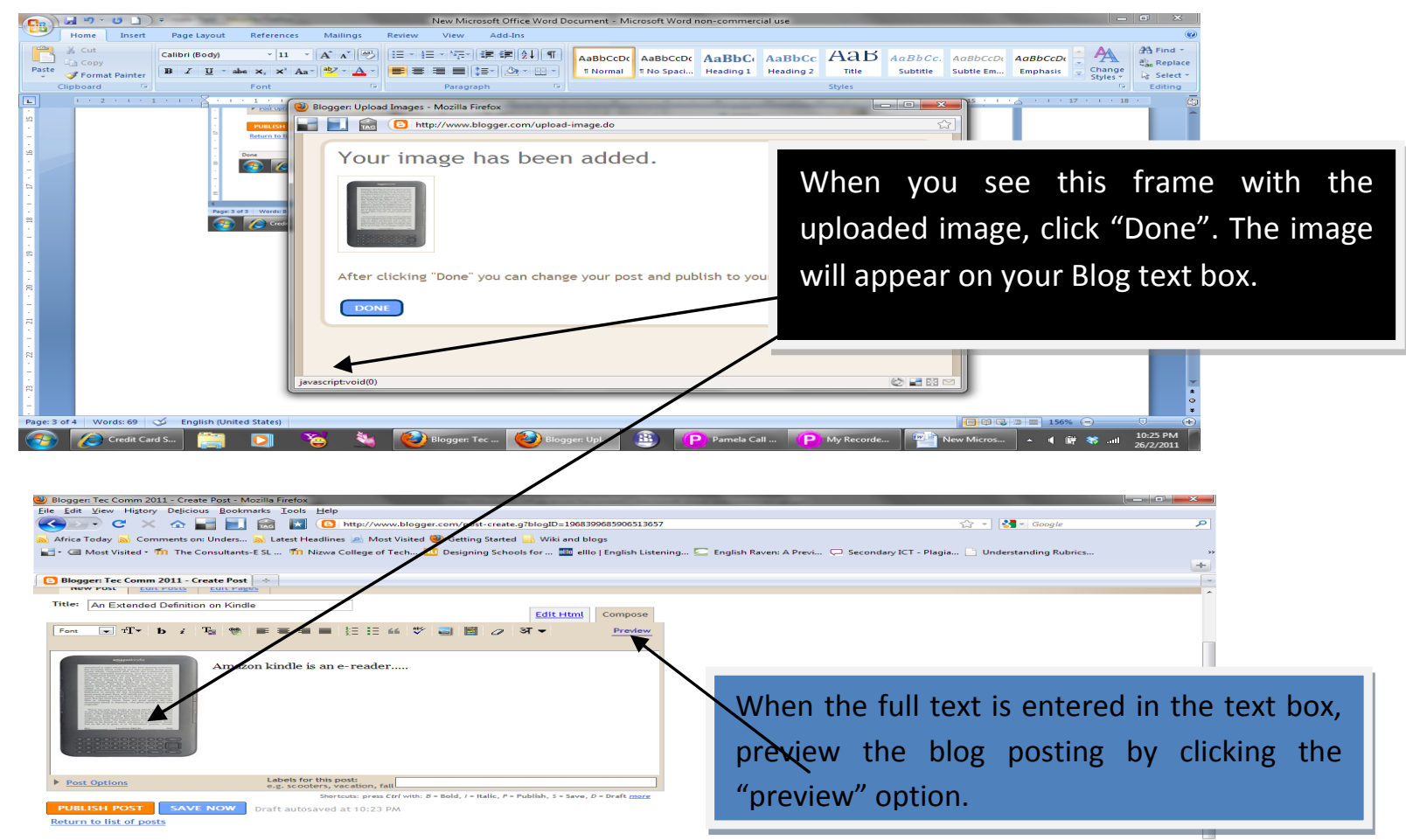

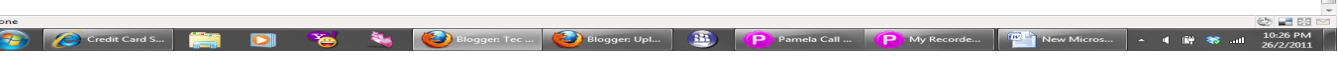




\section{Posting the blog:}

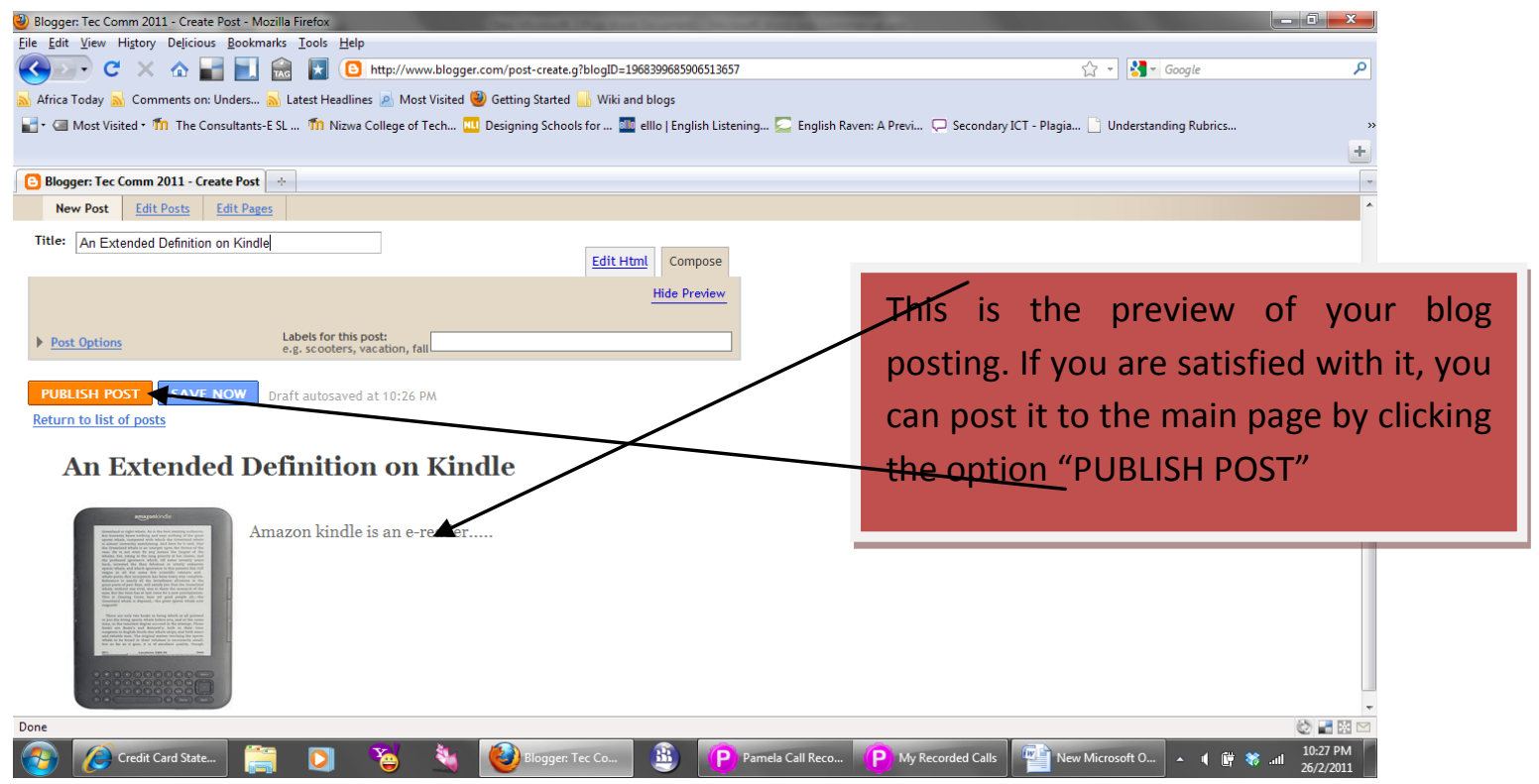

Appendix VI. How to add a comment to the Blog postings?

1. When you get an invitation mail from your tutor to join the blog, open the mail and it will look like this:

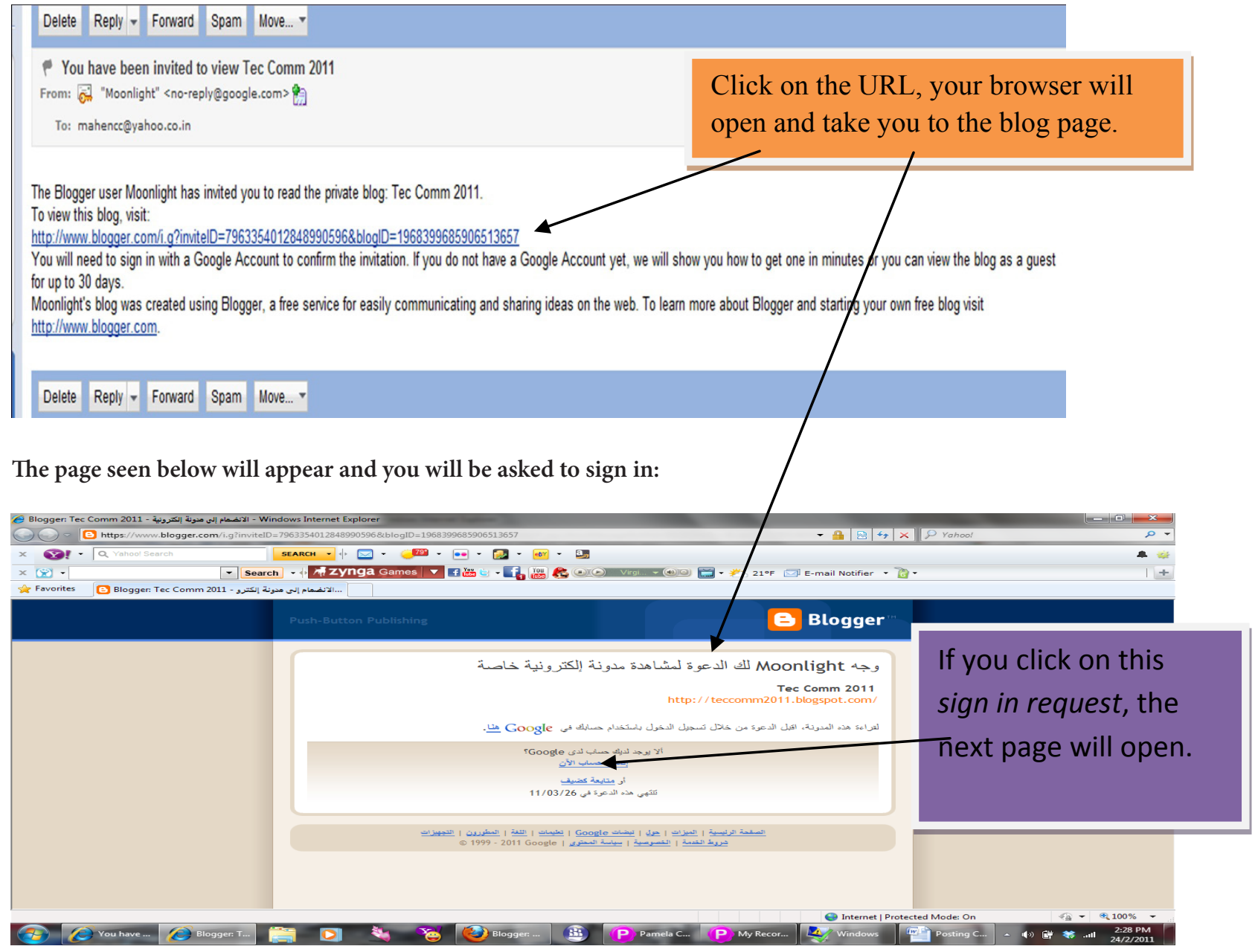


2. On the next page you will see the Blog Get started page. You can sign in to the Blog with your gmail ID.
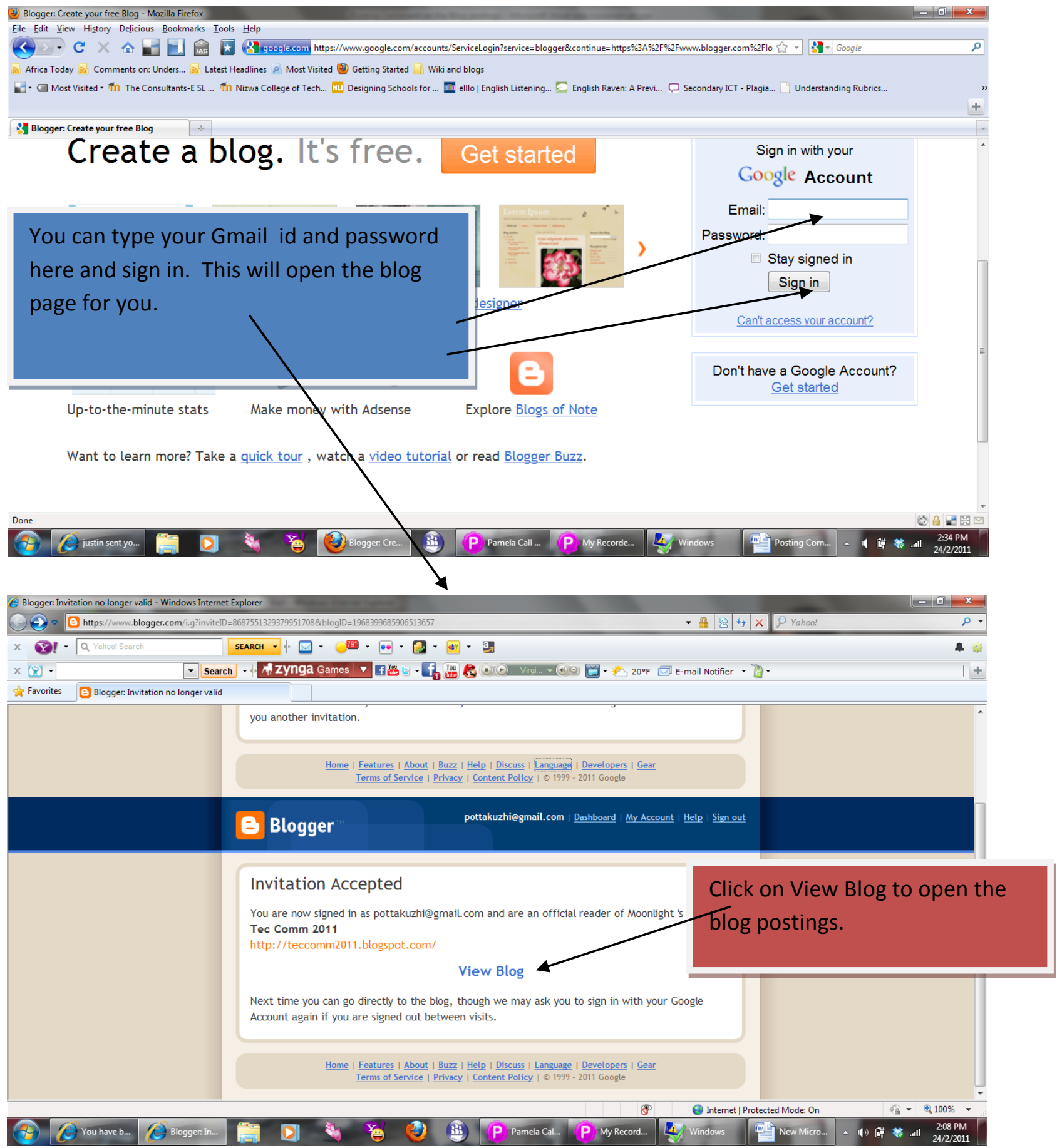
Appendix VII.

1. Screenshots of blog posting by students:

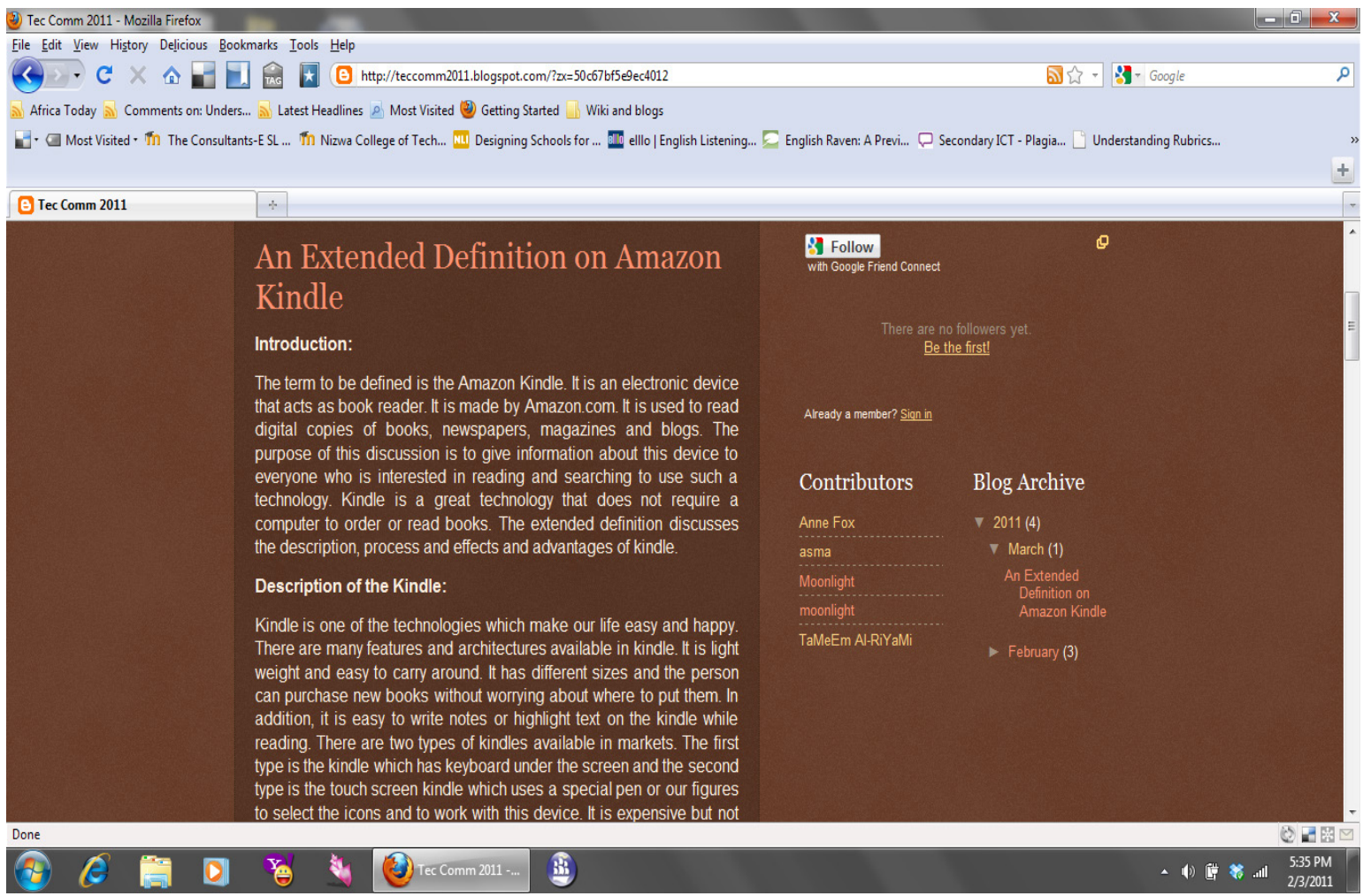

Appendix VIII.

1. A screenshot of teacher's comment

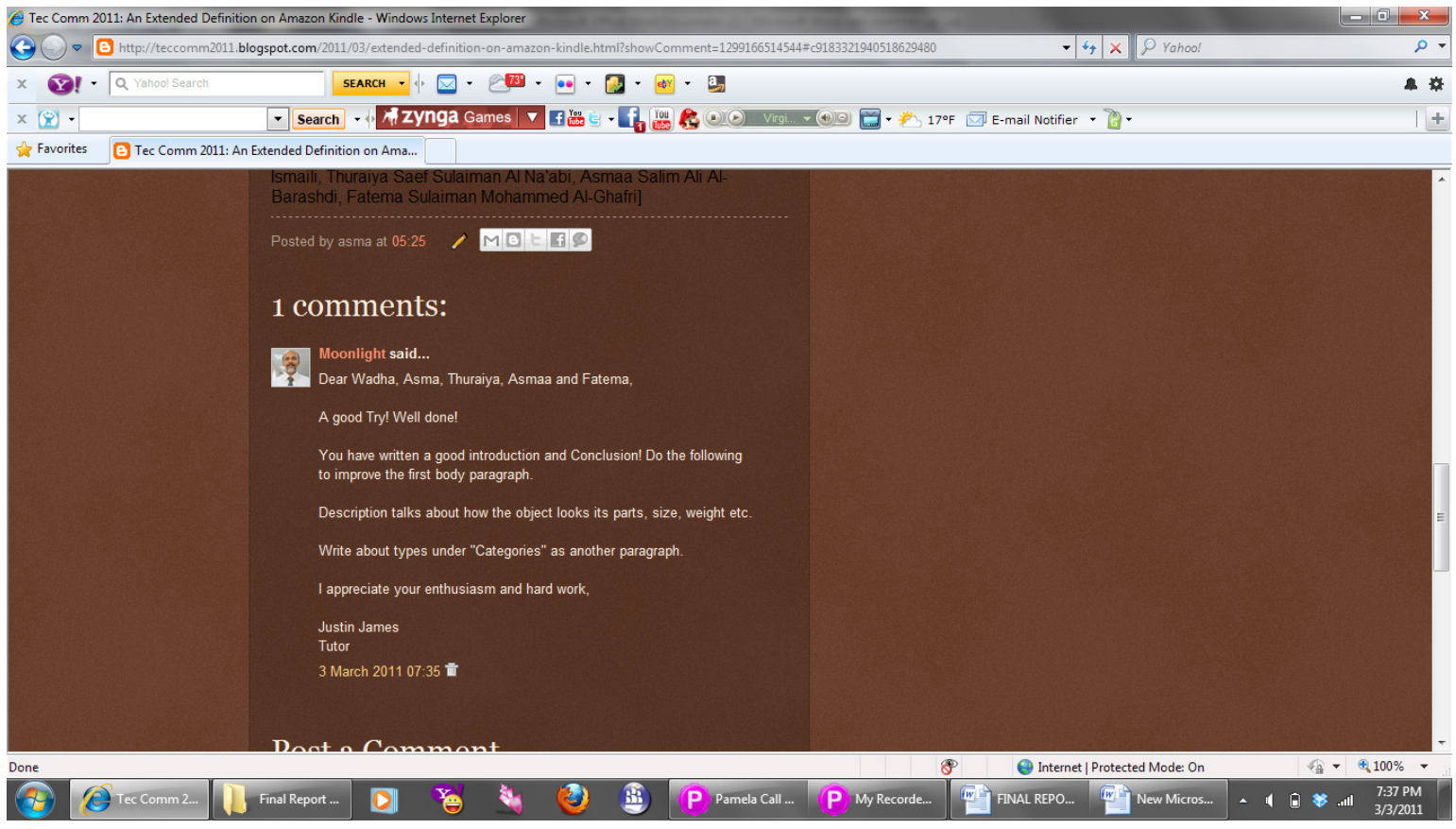

